\title{
Mechanisms under Metformin and Rapamycin as Anti-aging Drugs
}

\author{
Qian Feng ${ }^{1}$, Bangwei Chen ${ }^{1}$, Chuyao Wang ${ }^{1}$, Chao Nie $^{2}$, and TAO LI ${ }^{1}$ \\ ${ }^{1}$ Affiliation not available \\ ${ }^{2}$ BGI-Shenzhen
}

July 2, 2020

\begin{abstract}
As percentages of elderly people rise in many societies, age-related diseases have become more prevalent. Research interests have been shifting to delaying age-related disease by delaying or reversing aging itself. We use metformin and rapamycin, two drugs at the center of anti-aging drug research, as an entry point to talk about important molecular and genetic anti-aging mechanisms that have been extensively studied with them, such as mTOR, AMPK, and epigenetic modifications. We also present a number of observational studies, animal studies, and clinical trials to reflect the potential and actual effects of the mechanisms. At the end, we list remaining concerns that not only apply to researches around metformin and rapamycin but also future researches to explore other anti-aging pathways and therapeutics.
\end{abstract}

\section{Introduction}

The life expectancy in many countries is projected to exceed 85 years by $2030 .{ }^{1}$ Globally, one quarter of the population is expected to be in their sixties or older in $2050 .^{2}$ Nonetheless, the unprecedented longer life expectancy heralds a staggering number of people living with age-related diseases and considerable burdens on the social, economic, and healthcare systems worldwide. There is a pressing need to combat the challenges posed by age-related diseases and increase the health span of humans. However, while age-related diseases can often coexist, current delivery of health services and research efforts have continued to deal with the diseases ineffectively in an insular fashion. ${ }^{3}$ In contrast, mechanisms that account for the phenotypes of old age, such as impaired metabolism, dysregulated immune profile, and abnormal DNA methylome, have been shown to be the underlying determinants of many chronic diseases. ${ }^{4}$ Therefore, modifying the mechanisms of aging directly seems to be a more productive approach to fundamentally curb the growth of chronic diseases.

Although aging has been traditionally considered an irreversible process, encouragingly, a growing number of studies have indicated that metformin and rapamycin, two drugs that have been used extensively to treat type 2 diabetes (T2DM) and as an immunosuppressant respectively, have the potential to stall aging and delay the onset of age-related diseases. In this review, we survey a selection of articles about metformin and rapamycin to give a glance of the anti-aging mechanisms that have been studied with these two drugs and their extent of effectiveness. Finally, remaining questions and concerns are highlighted to guide future anti-aging research.

\section{Longevity}

Almost all life forms constantly sit on a balance between production and maintenance, and under low nutrient conditions when reproduction is more challenging, in order to ensure reproductive success, increasing somatic 
maintenance is necessary to prolong the reproductively competent period and consequently, lifespan. ${ }^{5}$ Hence, calorie restriction $(\mathrm{CR})$ without malnutrition is one of the most reliable approaches in extending both lifespan and healthspan in various vertebrate and non-vertebrate species. However, CR is difficult to sustain and implement since individuals must remain in a state of hunger and endure feelings of starvation, fatigue, and irritations. Besides, individuals who practiced CR are more susceptible to viral infections ${ }^{6}$ and resistant to wound-healing ${ }^{7}$, both of which impede its widespread use. Alternatively, metformin and rapamycin can act as calorie-restriction mimetics (CRM) by triggering the nutrient sensing pathways that sense and respond to the changing intracellular and extracellular energy and nutrient levels without actually restricting calorie intake. $^{8}$

Rapamycin and metformin target respectively the mechanistic target of rapamycin (mTOR) and 5'-AMPactivated protein kinase (AMPK) (Fig.1). The mTOR comprises of two complexes, mTORC1 and mTORC2, and they coordinate a wide range of cellular metabolic processes concerning production, growth, and somatic maintenance, such as protein synthesis, mitochondrial function, and cell proliferation. Activated mTORC1 enhances mRNA translation and protein synthesis in the cell by phosphorylating the p70 ribosomal protein $\mathrm{S} 6$ kinase $(\mathrm{S} 6 \mathrm{~K})$ and eukaryotic translation initiation factor $4 \mathrm{E}-$ binding protein 1 (4E-BP1) ${ }^{9}$ it also suppresses autophagy by phosphorylating ULK1, ULK2, and ATG13 of the ULK complex and the transcription factor EB, both of which essential for the autophagy process. ${ }^{10}$ Not surprisingly, mounting studies have shown that deregulated mTOR signaling is implicated in the aging process and the progression of age-related disease such as cancer and diabetes. ${ }^{10,11}$ Rapamycin suppresses mTOR signaling by first binding to its immunophilin FK binding protein (FKBP12) and then acting upon mTORC1 and mTORC2. ${ }^{12}$ While inhibiting mTORC1 extends life expectancy and confers protection for age-related diseases, inhibiting mTORC2 is associated with unwanted effects such as glucose intolerance and abnormal lipid profiles. Nevertheless, mTORC2 is less sensitive to rapamycin and its inhibition can only be achieved through long-term treatment. ${ }^{13}$

AMPK is the upstream controller of the mTOR signaling pathway (Fig. 1). Numerous studies have indicated that the activating capacity of the AMPK signaling pathway declines with aging, and its decline disturbs autophagy, increases cellular stress, and promotes inflammation, which further provoke many age-associated diseases, such as cardiovascular disease, diabetes, and cancer. ${ }^{9,14}$ Correspondingly, increased activation of the AMPK pathway has been shown to extend lifespan in lower organisms in response to CR and pharmaceutical agents, such as metformin. ${ }^{15}$ Activated AMPK phosphorylates and activates ULK1 of the ULK complex to promote autophagy as well as activates the FOXO transcription factors that transactivate the genes involved in detoxification, autophagy, tumorigenesis suppression, and energy homeostasis. ${ }^{5}$ Furthermore, AMPK activation attenuates the aging process by inhibiting $\mathrm{NF}-\varkappa \mathrm{B}$, the major regulator of innate and adaptive immunity, and relieves ER stress and oxidative stress by promoting the expression of mitochondrial uncoupling protein (UCP-2). ${ }^{16}$

Metformin and rapamycin are also implicated in DNA methylation, an omnipresent regulatory mechanism for gene expression in our genome. DNA methylation is facilitated by DNA methyltransferases DNMT3A, DNMT3B, and DNMT1 and adds a methyl group to the $5^{\text {th }}$ carbon on cytosine. DNA methylation usually leads to gene silencing by interacting with transcription mechanisms, and global hypomethylation and promoter hypermethylation are often observed in aged people. ${ }^{17}$ Since DNA methylation is reversible, it is a promising target for therapeutic interventions.

Rapamycin regulates DNA methylation by inhibiting the mTOR signaling pathway to reduce serine production and glycolytic metabolism, which tune down the serine and $1 \mathrm{C}$ metabolism that uses serine to produce SAM, the methyl donor in the methylation reaction. ${ }^{18}$ Metformin alters methylomes globally via the H19/SAHH axis. H19, a long noncoding RNA that should be downregulated in adults, causes an aberrant methylation profile by binding to and inhibiting s-adenosylhomocysteine hydrolase (SAHH), which normally hydrolyzes s-adenosylhomocysteine (SAH) and removes its inhibition of DNMT3B. Metformin activates AMPK and upregulates let-7, a family of microRNAs that bind to and degrade H19. ${ }^{19}$

Quite a few studies have corroborated the proposed life-extending effects of metformin and rapamycin. Metformin has been shown to extend healthspan and lifespan in the roundworm C. elegans (Table 1). ${ }^{20}$ 
Furthermore, a low dose of metformin supplemented for middle-aged male mice's diet lead to a $5.83 \%$ extension of mean lifespan. ${ }^{21} \mathrm{~A}$ longitudinal study that compares the methylation profiles of the white blood cells from 12 healthy individuals at the beginning, 10 hours, and 7 days after metformin treatment revealed 11 consistently differentially methylated sites. By looking at the associated genes, regions, and networks, the study found several related genes including CAMKK1, a regulator of AMPK and glucose uptake, BACE2, involved in neurodegenerative disorders and insulin production, and ADAM8, which is related to monocyte adhesion and migration and contributes to disorders caused by excessive inflammation such as neurodegenerative disorders, allergy, asthma, and acute lung inflammation. As the cells were from healthy individuals, having ADAM8 in the result shows that metformin's anti-inflammatory effect is independent of diabetic status. $^{22}$

Treating yeast with rapamycin resulted in extended lifespan in a process that has been postulated to mimic $\mathrm{CR} .{ }^{23}$ Heterogeneous male mice that received a daily dosage of $2.24 \mathrm{mg}$ of rapamycin per $\mathrm{kg}$ of body weight beginning at the age of 20 months had $9 \%$ extended lifespan while female mice had $14 \%{ }^{24}$ In another mice study, the Intervention Testing Program (ITP), genetically outbred mice were used to test the potential of multiple anti-aging manipulations including drugs, diets, and other interventions, and rapamycin was one of the only two drugs that had robust anti-aging effects. ${ }^{25}$ Mice treated with rapamycin at $42 \mathrm{mg} / \mathrm{kg}$ from 4 -month to 22-month old had a 6-month decrease on average in epigenetic aging compared with control mice. ${ }^{26}$ Moreover, healthy participants in a double blind randomized study aged 65 and older who had taken Everolimus, also a mTOR inhibitor, for 6 weeks then stopped for 2 weeks before a flu shot was given to them had $20 \%$ stronger immune responses compared with the control, suggesting that a low dose of rapamycin may delay immunesenescence in the elderly instead of suppressing their immune system. ${ }^{27}$

\section{Cardiovascular Diseases}

Cardiovascular diseases (CVDs), marked by lipid-rich plaques accumulating in blood vessels, are the leading cause of death globally, claiming around 17.9 million lives per year. ${ }^{28}$ While CVDs arise from a complex combination of hereditary predisposition and environmental factors including lifestyle, aging is the dominant factor. ${ }^{29}$ In the US, roughly $70 \%-75 \%$ of people who are $60-79$ years old are afflicted with CVDs. ${ }^{30}$

Dyslipidemia, insulin resistance, and chronic inflammation that commonly occur in older people make them more susceptible to CVDs. AMPK activation by metformin can suppress fatty-acid desaturase (FADS) genes, reducing the circulating levels of lipid metabolites and LDL cholesterol. ${ }^{31}$ Metformin also improves insulin sensitivity, helps losing weight, and reduces perceived hunger and food intake. ${ }^{32}$ Recently, growth differentiating factor 15 (GDF15) was found to contribute to the weight loss effect of metformin by interacting with the GFRAL receptor in the central nervous system to suppress appetite. Metformin mediates GDF15 increase by promoting transcription of CHOP and ATF4 most prominently in the liver and gastrointestinal system. ${ }^{33,34}$ Although metformin does not directly affect coronary artery disease through the GDF-15 pathway, the GDF-15 dependent weight loss effect may contribute to higher insulin sensitivity. ${ }^{35}$ Metformin also inhibits vascular inflammation that can lead to plaque formation by blockading the PI3K-Akt pathway and its downstream NF- $\chi$ B pathway. ${ }^{36}$ Furthermore, mitochondria dysfunction and endothelial senescence contribute to higher risks of CVDs, and activated AMPK increases SIRT3 levels and improves mitochondrial biogenesis and function by enhancing trimethylation of H3K79 via the SIRT-DOT1L axis. SIRT3 also delays endothelial senescence by upregulating telomere reverse transcriptase expression. ${ }^{37}$ Less is known about the protective effects of rapamycin, but a study found that mTOR inhibition suppressed DNMT1 upregulation caused by disturbed flow in the blood vessels bothin vitro and in vivo.$^{38}$

Metformin's protective effects have been confirmed in both animal and human studies. Chronic low doses of metformin given to ApoE deficient mice that have poor lipid-clearing capabilities and age-related atherosclerosis showed positive effects as well as reduced recruitment of macrophages into subendothelial space of aorta and decreased levels of pro-inflammatory cytokines. ${ }^{37}$ Bovine aortic endothelial cells exposed to clinically relevant amounts of metformin have increased activities of nitric oxide synthase (eNOS), endothelium-derived 
nitric oxide (NO), and AMPK while no such effect is observed in AMPK knockout mice. NO and eNOS have major roles in maintaining vascular homeostasis and its integrity, suggesting that AMPK activation by metformin exerts vascular-protective effects. ${ }^{39,40}$ Treating 32 weeks old mice with metformin at $200 \mathrm{mg} / \mathrm{kg}$ per day for 4 weeks also partially reversed left ventricular dilatation caused by $\delta$-sarcoglycan deficiency: the hearts showed less fibrosis, less cardiomyocyte hypertrophy, and fewer degenerative subcellular changes. At the same time, there were also increased autophagy, increased AMPK activity, and suppressed mTOR phosphorylation. ${ }^{41}$ Diabetic veterans (mostly white male) who took metformin had lower CVDs and mortality risks compared with those who took sulfonylureas, and similar results were obtained in another clinical trial that compares the CVD risk associated with glipizide and metformin. ${ }^{42,43}$ Although in these studies it could not be determined whether the result was caused by the benefits of metformin or damages due to sulfonylureas or both, metformin's protective effects could be more ascertained in the United Kingdom Prospective Diabetes Study (UKPDS), in which metformin treatment conferred a significantly lower incidence of myocardial infraction $(33 \%, \mathrm{P}=0.005)$ compared with dietary therapy for diabetic patients. ${ }^{44}$ Furthermore, several clinical trials and meta analyses have found metformin to decrease CVD risk for not just diabetic people, but pre-diabetic and non-diabetic people as well. ${ }^{45,46}$

\section{Tumors}

The risk of fatal cancer development increases exponentially with age, and around $60 \%$ of cancers are diagnosed in people 65 years or older. Activation of oncogenes and shutdowns of tumor suppressor genes result in reprogrammed energy metabolism and uncontrolled cell growth and division. ${ }^{47}$ Hence, it makes sense that over-activation of mTORC1 signaling has been observed in many types of cancer such as lymphoma, endometrial cancer, and renal cell carcinoma. ${ }^{48-50}$ Activated mTORC1 promotes aerobic glycolysis by increasing the amount of hypoxia inducible factor (HIF)-1 $\alpha$, a transcription factor that is associated with metastasis by promoting angiogenesis responding to hypoxia. ${ }^{51}$ It also indirectly upregulates genes involved in lipogenesis by phosphorylating Lipin-1 and S6K-1, which activates SREBP-1, a lipogenic transcription factor. ${ }^{52,53}$ Additionally, phosphorylating S6K1 enhances biosynthesis of purine and pyrimidine, two amino acids required for cancer cell proliferation. ${ }^{54} \mathrm{As}$ the potent inhibitor of mTORC1, rapamycin can put a brake on the defective tumor metabolism and has been investigated as a promising drug to treat cancer. In 2002, rapamycin was first reported to have antineoplastic properties in mice by suppressing cancer metastasis and angiogenesis. ${ }^{55}$ Since then, overwhelming in vivo and in vitro studies have reported that rapamycin and its derivatives have the potential of ameliorating cancer onset and development, and hundreds of clinical trials have been conducted to test monotherapy or combination therapies of rapamycin. ${ }^{24,56}$ For instance, rapamycin treatment decreased both phenotypic progression of tumor and tumor size in mice exposed to the tobacco carcinogen NNK and had lung cancer. ${ }^{57}$ Nevertheless, the actual clinical benefits of rapamycin and rapalogs have been mostly modest. ${ }^{58,59}$ In a study using transgenic HER-2/neu cancer prone mice, although rapamycin did not extend the lifespan of the mice with established tumor, it effectively delayed spontaneous tumor onset in others and extended their lifespan, suggesting its potential as a measure to prevent cancer. ${ }^{56}$

Multiple studies have also supported that the growth inhibition caused by metformin's interaction with the AMPK/mTOR pathway to be effective against various cancers including lung cancer, breast cancer, and colorectal cancer. ${ }^{60}$ Metformin delayed the first tumor onset by $22 \%$ and $25 \%$ respectively in female mice at the age of 3 months and 9 months. ${ }^{61}$ Furthermore, metformin inhibited NNK-induced lung cancer cell proliferation in mice by decreasing the levels of circulating insulin and IGF-1, which suppressed the IIS pathway and downregulated the downstream PI3K-Akt and mTOR signaling pathway (Fig. 1) ${ }^{62}$ In endometrial cancer cells, metformin significantly reduced the levels of Ki-67, an indicator of tumor progression, topoisomerase II $\alpha$, associated with DNA instability, and phospho-ribosomal protein S6 and phospho-ERK 1/2, both of which activated by mTOR. Significantly increased AMPK and p27 levels and subsequent cell cycle inhibition were also observed. ${ }^{63} \mathrm{H} 19$ is found in almost all cancer cells. Genome-scale DNA methylation profiling showed that tumor promoting pathway genes became repressed and genes involved in neuronal development, cell morphology, and intracellular communication were activated after metformin treatment. Interestingly, 
the H19 gene was also inactivated, suggesting a feed-forward response to continuously suppress H19 can be established by metformin. ${ }^{19}$ In addition, the 11 metformin-induced differentially methylated CpG sites mentioned earlier were related to multiple tumor-related genes: SIX3 is downregulated in lung cancer due to promoter methylation, which was rescued by metformin. POFUT2 is linked to glioblastoma and adenocarcinoma. MUC4 is implicated in pancreatic cancer. KIAA1614 is related to colon cancer. Lastly, UPF1 is associated with genome stability. The differentially methylated regions included the gene EPHB1, whose underexpression leads to gastric carcinoma and invasion of colorectal cancer cells, and SERP2, which is positively correlated with BMI and abnormal glucose tolerance as well as colorectal cancer. Pathway enrichment analysis found association between the CpG sites and the unfolded protein response, which is involved in metformin-induced apoptosis in acute lymphoblastic leukemia. ${ }^{22}$ In 2005 , a case control study first discovered reduced risk of cancer associated with metformin in diabetic patients. ${ }^{64}$ Compared with people who took sulfonylureas, insulin, and other anti-diabetic drugs, metformin users had a significantly lower risk of cancer (Hazard Ratio [HR] 0.63, 95\% Confidence Interval [CI] [0.53-0.75]). ${ }^{65}$ Diabetic patients who took metformin also had $7 \%$ less chance of getting hepatocellular cancer for each incremental year they took metformin, and it was attributed to inhibited proliferation and cell cycle arrest induced by metformin in the hepatocytes. ${ }^{6}$ Nevertheless, there are studies that do not support metformin's beneficial role in cancer. Evidence from randomized control trials has been large inconclusive. ${ }^{67,68}$ Additionally, in a study that compares metformin with rosiglitazone and sulfonylureas, metformin users did not show lower malignancy rates. ${ }^{69}$ Multiple metaanalyses also did not find any evidence showing metformin reduces cancer incidence. ${ }^{70,71}$ Work is still needed to resolve these inconsistencies.

\section{Neurodegeneration}

Alzheimer's Disease (AD) is a degenerative neurological disorder, accounting for $60-80 \%$ of dementia. ${ }^{72}$ AD affects up to one third of the population aged $>65$ years, making it the fifth leading cause of death globally. ${ }^{73}$ Currently no drug exists to treat or slow down the development of AD. Instead, patients use drugs such as cholinesterase inhibitors and glutamate inhibitors to prevent the breakdown of acetylcholine and the overexcitation of neurons to amend their impaired cognitive functions. ${ }^{74-77}$

Applying metformin to treat AD stems from the widely observed association between AD and type 2 diabetes mellitus (T2DM). In 20 non-diabetic AD patients, treatment with metformin for 8 weeks resulted in improved cognitive functions (Koenig, Mechanic-Hamilton et al.). ${ }^{78}$ Nonetheless, a larger study that analyzed data from 7,086 dementia patients and matching number of healthy controls from the United Kingdom-based General Practice Research Database (GPRD) concluded otherwise; Individuals who did not receive any drug for diabetes $(\mathrm{AOR}=0.88,95 \% \mathrm{CI}=0.71-1.10)$ or those who took antidiabetic drugs $(\mathrm{AOR}=1.03,95 \%$ $\mathrm{CI}=0.90-1.19)$ had a similar risk of developing $\mathrm{AD}$ as individuals without diabetes $(\mathrm{AOR}=1) . \mathrm{Furthermore}$, patients who had been exposed to various anti-diabetic drugs and had received more than 60 prescriptions of metformin had increased the risk of developing $\mathrm{AD}(\mathrm{AOR}=1.71,95 \% \mathrm{CI}=1.12-2.60)$, which was attributed to the production of A- $\beta$ peptides, a hallmark for AD. However, the increased risk was not confirmed in patients who had taken metformin exclusively $(\mathrm{AOR}=1.00,95 \% \mathrm{CI}=0.55-1.81,>30$ prescriptions $)$, and there was no trend of increasing risk of $\mathrm{AD}$ with increasing number of metformin prescriptions. ${ }^{79}$ The increased production of A- $\beta$ peptides caused by metformin was explained on cell cultures of primary cortical neurons and N2a neuroblastoma cells expressing human amyloid precursor protein (APP). Metformin upregulates the transcription of $\beta$-secretase, which cleaves APP into A- $\beta$ peptides. Intriguingly, metformin combined with insulin reduced A- $\beta$ peptide levels. ${ }^{80}$ In another study which diabetes model mice were used to evaluate AD-like brain changes and the effect of metformin on those changes, metformin attenuated the increase of total tau, phospho-tau, and activated JNK, a tau kinase, in the mice. Metformin also attenuated the decrease of synaptophysin and preserved the neural structures, but did not improve spatial learning and memory abilities. ${ }^{81}$ These studies together suggest that having taken metformin in the past does not reduce the risk of $\mathrm{AD}$, but metformin used with insulin may be an effective short-term treatment. 
Dysregulated mTOR activity and autophagy have been observed in patients with early Alzheimer's disease. ${ }^{82}$ $\mathrm{AD}$ and mTOR's connection has also been shown in a genome wide association study (GWAS), in which it identified 5 significant SNPs (rs6723868, rs30986, rs27709, rs26840, rs27648) that had to do with cerebellar age acceleration, defined to be negative when the epigenetic age is less than the chronological age (Table 2 ). Correlating the SNPs with mRNA levels of neighboring genes found genes that overlapped with those related to $\mathrm{AD}$, age related macular degeneration, and Parkinson's disease (PD). Among them, the gene MLST8 was significantly correlated with cerebellar age acceleration, and MLST8 is an integral part of the mTOR complexes. ${ }^{83}$ Hence, the mTOR inhibitor rapamycin has also been investigated to treat AD. Mice with increased mTOR activity had higher levels of tau and Aßlevels. ${ }^{84}$ Administrating rapamycin to young $3 x T g-A D$ mice induced mTOR-mediated autophagy and reduced $\mathrm{A} \beta$ and tau levels. ${ }^{85}$ Nonetheless, rapamycin could only accelerate autophagy of tau and plaques before their formation: a significant reduction of tau and plaques was observed when treating $\mathrm{AD}$ mice at 2 months with rapamycin while at 15 months the treatment had no such effect. ${ }^{86}$ Moreover, administering rapamycin to APOE4 mutant carrier mice, a transgenic AD mice model, resulted in restored cerebral blood flow and maintenance of blood-brain barrier integrity, pointing to rapamycin's beneficial role in reducing vascular progression in $\mathrm{AD} .^{87}$

PD is known for tremors, difficulty in walking, and muscle rigidity in its patients due to dysfunction of the motor system. ${ }^{88} \mathrm{PD}$ affects around $1 \%$ of people aged $>60$ years. ${ }^{89}$ Loss of dopaminergic neurons is characteristic of PD and leads to a decreased amount of dopamine as well as imbalance between dopamine and acetylcholine. According to the acetylcholine-dopamine balance hypothesis, over-activation of cholinergic system activity causes motor and cognitive disturbances. Hence, the current PD drugs either provide more dopamine or reduce the amount of acetylcholine to restore the balance, working as a remedy instead of neuroprotective agents. ${ }^{90-92}$

PD, diabetes, and dementia share the disorder of mitochondrial bioenergetics and abnormal protein folding in their pathogenesis, and several studies have found metformin to alleviate PD. An analysis of a cohort of 800,000 people from the Taiwan National Health Insurance database showed that having T2DM increased the risk of PD 2.2-fold, and metformin-inclusive sulfonylurea therapy reduced the risk $(\mathrm{HR}=0.78$ relative to diabetes-free, $95 \% \mathrm{CI}=0.61-1.01) .{ }^{93}$ The reason has to do with metformin's ability to reduce $\alpha$-synuclein release, a component of the Lewy bodies and Lewy neurites that are characteristic of PD. MPTP, a prodrug to the neurotoxin $\mathrm{MPP}+$, was used to damage the mice dopaminergic neurons, leading to astroglial activation, which increased release of $\alpha$-synuclein. Then metformin mitigated astroglial activation and promoted methylation of protein phosphatase 2A (PP2A), helping $\alpha$-synuclein dephosphorylation. AMPK activation by metformin also increased ATP production in mitochondria and restored mitochondria function. However, the timing and dosage of metformin was also critical. When MPTP and metformin were given in the same day, $75 \%$ lethality ensued in the mice. Although metformin increased the levels of two neurotrophic factors BDNF and GDNF, high dosage $\left(400 \mathrm{mg} / \mathrm{kg}\right.$ ) killed all the mice. ${ }^{94,95}$ In another study, metformin rescued tumor necrosis factor type 1 receptor associated protein (TRAP1) mutation associated changes in mitochondrial protein balance. TRAP1 is a protein associated with stress sensing in mitochondria, and its absence due to mutation has been identified to increase the risk for PD. Metformin reversed elevated mitochondrial respiration, reduced mitochondrial membrane potential, and imbalance of nuclear and mitochondrial protein production caused by the loss of TRAP $1 .{ }^{96}$ In summary, metformin intervenes the pathogenesis of PD by preserving neurons, reducing inflammation, and protecting mitochondria functions. It is a promising new help for PD patients, but further studies are still needed to understand the influence of dosage and timing.

\section{Discussion}

Although current research foreshadows a promising perspective for using metformin and rapamycin as antiaging drugs, there are still some concerns that need to be highlighted, and they apply not only to the researches of metformin and rapamycin, but to other anti-aging mechanism and anti-aging drug researches as well. 
First, despite the positive outcomes from many studies, it is not uncommon to find a change in dosage turning the result from life-extending to life-ending. When a low dose of metformin $(0.1 \%)$ was given to middle-aged male mice with their diet, their lifespans were extended by $5.83 \%$ on average, but a higher concentration (1\%) became toxic. ${ }^{21}$ In another study, although metformin activated AMPK and suppressed lipid storage in fruit flies, their lifespan did not increase. At higher doses $(25 \mathrm{mM}$ and $50 \mathrm{mM})$, metformin reduced the survival rates. The authors reasoned the causes to be excessive starvation, disrupted intestinal fluid homeostasis, or metformin toxicity. ${ }^{97}$ In the PD study with mice models created with MPTP, when MPTP and metformin were given in the same day, $75 \%$ lethality ensued in the mice. Furthermore, although metformin increased the levels of BDNF and GDNF, two neurotrophic factors, the high dosage (400 $\mathrm{mg} / \mathrm{kg})$ killed all the mice. ${ }^{95}$ The issues with dosage along with physical and genetic differences between humans and animals make scaling the positive lab results for human use a tricky matter. In the study that showed metformin's beneficial effects for treating CVDs in mice, the dosage was $200 \mathrm{mg} / \mathrm{kg}$, a number that can no way be applicable to humans. ${ }^{41}$ Hence, conducting human clinical trials may be a more efficient approach to find a safe and effective dosage for human use. Encouragingly, when anti-diabetic doses of metformin were given to 12 pre-operative endothelial cancer patients and comparison of their tissue samples before and after the operation were made, the same effects observed in vitro were found - increased AMPK phosphorylation, decreased tumor cell proliferation, and decreased H19 levels. ${ }^{19}$

Another issue that stands in the way is the side effects associated with chronic use of drugs. About $25 \%$ of patients treated with metformin have gastrointestinal side effects associated with the phenotype of organic cation transporter 1 (OCT1). ${ }^{98}$ Besides, chronic use of metformin can cause dose-dependent vitamin B12 deficiency, increasing the risk for anemia and neuropathy. ${ }^{99,100}$ Lactic acidosis has been reported as a side effect of metformin, but there has been controversies, and in the study using diabetes model mice to study AD-like brain changes, metformin did not further increase the serum lactate concentrations. ${ }^{81}$ Whether this holds true in healthy mice or humans is yet to be seen. As for rapamycin, over a third of users have reported diarrhea and nausea, accounting for around $5 \%$ of treatment discontinuation. ${ }^{101}$ The issues with side effects can be addressed in four ways: the first is to selectively take supplements, such as vitamin B12, to make up for the loss. The second is to reduce the dose and increase the interval between every dose. A small RCT suggests short-term use of rapamycin to be relatively safe approach. ${ }^{102}$ Intermittently administering $2 \mathrm{mg} / \mathrm{kg}$ of rapamycin every 5 days has also reduced incidence of side effects in mice and extended their lifespan. ${ }^{103}$ More clinical trials are needed to calibrate the balance between safety and anti-aging effectiveness. The third way is taking a variety of anti-aging drugs (also known as drug cocktail therapy), each with a very low dose, instead of taking only metformin or rapamycin since the side effects are dose-dependent. Although cultured cells and a mice study both showed metformin combined with insulin reduced A- $\beta$ peptide levels, ${ }^{80,81}$ the GPRD study showed long-time combined exposure to metformin and other anti-diabetic drugs increased the risk of $\mathrm{AD}$ while using only metformin did not show any difference. ${ }^{104}$ Therefore, this method requires further validation as well. The fourth way is to find analogs with fewer side effects. Recent study found DL001, an effective mTORC1 specific rapalog, does not induce metabolic disruption and immunesuppression. ${ }^{105}$ Furthermore, a low dose of rapalog (RAD001) combined with the catalyst BEZ235 reduced infection by $40 \%$ and improved response to influenza vaccination in healthy elderly (aged 65 and older) subjects. More importantly, this combination therapy was well-tolerated in majority of the subjects. ${ }^{106}$ Rapalogs have been approved for treating multiple cancers, including renal cell carcinoma, hepatocellular carcinoma and mantle cell lymphoma, making it by far the most promising way to circumvent the side effects of rapamycin. ${ }^{107,108}$ Nevertheless, as reported clinical benefits have been modest, ${ }^{58,59}$ the quest for more effective rapalogs is still ongoing. On the other hand, metformin had fewer available analogs with well-studied side effects. Phenformin and buformin, which are biguanide drugs like metformin, were withdrawn from the market due to fatal lactic acidosis. ${ }^{109}$ Mito-metformin, synthesized by adding a positively charged triphenylphosphonium group to metformin, showed 100-fold to 1000-fold more anti-proliferative effects depending on alkyl chain lengths, but how the drastically improved potency will impact healthy cells is poorly understood at the moment. ${ }^{110}$

Future research should also work to elucidate how gender influences drug effectiveness. Metformin increased 
mean lifespan of female mice by $4.4 \%$ while decreased that of male mice by $13.4 \% .{ }^{111}$ Male pre-diabetic patients who received metformin had a significantly lower coronary calcium score compared with control while the female group did not. ${ }^{46}$ Such sexual dimorphism also affects the lifespan of mice that took rapamycin female mice had greater lifespan increase than male mice did. ${ }^{24,112}$ These studies have showed varied amount by which gender influences drug effectiveness, and studying drug-hormone interactions could help finding the reason.

Besides these issues, much more can be found about the genetic mechanisms that regulate lifespan. Although many positive outcomes have come out of attempts to control DNA methylation with metformin and rapamycin, the full picture of epigenetic modifications have not been understood. Metformin treatment led to a combination of hyper, hypo, and non-differentially methylated $\mathrm{CpG}$ sites, and this was due to a combination of direct and indirect effects. For example, hypermethylation of one site can lead to reduced expression of a protein, and this can have downstream effects that alter methylation status of other sites. ${ }^{19}$ Understanding this complex network of interactions will not only promote further understanding of metformin and rapamycin, but also help developing more anti-aging measures. APOE, a locus on chromosome 5q33.3, and FOXO3A are all known to correlate with longevity. It has also been mentioned above that a GWAS identified 5 SNPs related to cerebellum aging. ${ }^{83}$ In addition, SNPs in the human genome also affects the efficacy of drugs. For example, rs2740574, located in CYP3A4 changes breast cancer cells' response to rapamycin by altering drug metabolisms in liver, and rs2282143, located in SLC22A1, changes breast cancer cells' response to metformin by affecting the rate of drug entering cells. ${ }^{113} \mathrm{~A}$ locus on chromosome 11 (rs11212617) is associated with the glycemic response to metformin. ${ }^{114}$ Three SNPs (rs8111699, rs11212617, rs9803799), which are located in the LKB1, ATM and PRKAA2, have been identified as significant influencers on metformin therapy by affecting the AMPK pathway. ${ }^{115-117}$ As DNA sequencing becomes more convenient and accessible, it is reasonable to assume that increasing amount of genetic data and research efforts will reveal many more such connections, and they can point to novel genes and drug targets or be used for precision medicine to improve current treatments.

The issues of dosage, side effects, sexual dimorphism, and genetic regulatory mechanisms all point to the need for a large-scale clinical trial. The Targeting Aging with Metformin (TAME) trial is a large placebocontrolled trial that has been designed to enroll 3000 subjects to test whether metformin delays age-related diseases. ${ }^{118}$ The TAME trial received FDA approval in 2015, and after receiving all the required budget in 2019, it was set to start at the end of the same year. The TAME trial may make metformin the first approved drug for anti-aging, but more importantly, since it is not testing metformin against a single disease but a collection of age-related ones, it establishes aging as a medical condition that can be intervened or treated instead of an irreversible process outside human control. The shift in the notion of aging will make future anti-aging clinical trials proceed with much more ease. ${ }^{119}$

\section{References}

1. Kontis V, Bennett JE, Mathers CD, Li G, Foreman K, Ezzati M. Future life expectancy in 35 industrialised countries: projections with a Bayesian model ensemble. Lancet [Internet]. 2017;389(10076):1323-35. Available from: https://www.ncbi.nlm.nih.gov/pubmed/28236464

2. World Population Prospects: the 2017 Revision [Internet]. 2017. Available from: https://esa.un.org/unpd/wpp/Publications/Files/WPP2017_KeyFindings.pdf

3. Divo MJ, Martinez CH, Mannino DM. Ageing and the epidemiology of multimorbidity. Eur Respir J [Internet]. 2014;44(4):1055-68. Available from: https://www.ncbi.nlm.nih.gov/pubmed/25142482

4. Tchkonia T, Kirkland JL. Aging, Cell Senescence, and Chronic Disease: Emerging Therapeutic Strategies. JAMA [Internet]. 2018;320(13):1319-20. Available from: https://www.ncbi.nlm.nih.gov/pubmed/30242336

5. Efeyan A, Comb WC, Sabatini DM. Nutrient-sensing mechanisms and pathways. Nature [Internet]. 
2015/01/17. 2015;517(7534):302-10. Available from: https://www.ncbi.nlm.nih.gov/pubmed/25592535

6. Wang A, Huen SC, Luan HH, Yu S, Zhang C, Gallezot JD, et al. Opposing Effects of Fasting Metabolism on Tissue Tolerance in Bacterial and Viral Inflammation. Cell. 2016/09/10. 2016;166:1512-1525 e12.

7. Kristan DM. Calorie restriction and susceptibility to intact pathogens. Age. 2009/05/09. 2008;30:147-56.

8. Madeo F, Carmona-Gutierrez D, Hofer SJ, Kroemer G. Caloric Restriction Mimetics against AgeAssociated Disease: Targets, Mechanisms, and Therapeutic Potential. Cell Metabolism 2019.

9. Templeman NM, Murphy CT. Regulation of reproduction and longevity by nutrientsensing pathways. J Cell Biol [Internet]. 2017/10/28. 2018;217(1):93-106. Available from: https://www.ncbi.nlm.nih.gov/pubmed/29074705

10. Saxton RA, Sabatini DM. mTOR Signaling in Growth, Metabolism, and Disease. Cell [Internet]. 2017/04/08. 2017;169(6):960-76. Available from: https://www.ncbi.nlm.nih.gov/pubmed/28283069

11. Paquette M, El-Houjeiri L, Pause A. mTOR Pathways in Cancer and Autophagy. Cancers (Basel) [Internet]. 2018;10(1). Available from: https://www.ncbi.nlm.nih.gov/pubmed/29329237

12. Schreiber KH, Ortiz D, Academia EC, Anies AC, Liao CY, Kennedy BK. Rapamycin-mediated mTORC2 inhibition is determined by the relative expression of FK506-binding proteins. Aging Cell [Internet]. 2015;14(2):265-73. Available from: https://www.ncbi.nlm.nih.gov/pubmed/25652038

13. Gaubitz C, Prouteau M, Kusmider B, Loewith R. TORC2 Structure and Function. Trends Biochem Sci [Internet]. 2016;41(6):532-45. Available from: https://www.ncbi.nlm.nih.gov/pubmed/27161823

14. Burkewitz K, Zhang Y, Mair WB. AMPK at the nexus of energetics and aging. Cell Metab. 2014/04/15. 2014;20(1):10-25.

15. Chen J, Ou Y, Li Y, Hu S, Shao LW, Liu Y. Metformin extends C. elegans lifespan through lysosomal pathway. Elife. 2017/10/14. 2017;6.

16. Cameron AR, Morrison VL, Levin D, Mohan M, Forteath C, Beall C, et al. Anti-Inflammatory Effects of Metformin Irrespective of Diabetes Status. Circ Res. 2016/07/16. 2016;119:652-65.

17. Johnson AA, Akman K, Calimport SRG, Wuttke D, Stolzing A, De Magalhães JP. The role of DNA methylation in aging, rejuvenation, and age-related disease. Rejuvenation Res. 2012 Oct 1;15(5):483-94.

18. Zeng J deng, Wu WKK, Wang H yun, Li X xing. Serine and one-carbon metabolism, a bridge that links mTOR signaling and DNA methylation in cancer. Vol. 149, Pharmacological Research. Academic Press; 2019 .

19. Zhong T, Men Y, Lu L, Geng T, Zhou J, Mitsuhashi A, et al. Metformin alters DNA methylation genome-wide via the H19/SAHH axis. Oncogene. 2017 Apr 27;36(17):2345-54.

20. Cabreiro F, Au C, Leung KY, Vergara-Irigaray N, Cocheme HM, Noori T, et al. Metformin retards aging in C. elegans by altering microbial folate and methionine metabolism. Cell [Internet]. 2013;153(1):228-39. Available from: https://www.ncbi.nlm.nih.gov/pubmed/23540700

21. Martin-Montalvo A, Mercken EM, Mitchell SJ, Palacios HH, Mote PL, Scheibye-Knudsen M, et al. Metformin improves healthspan and lifespan in mice. Nat Commun. 2013/08/01. 2013;4:2192.

22. Elbere I, Silamikelis I, Ustinova M, Kalnina I, Zaharenko L, Peculis R, et al. Significantly altered peripheral blood cell DNA methylation profile as a result of immediate effect of metformin use in healthy individuals. Clin Epigenetics [Internet]. 2018 Dec 13 [cited 2020 Jun 29];10(1). Available from: https://pubmed.ncbi.nlm.nih.gov/30545422/

23. Aliper A, Jellen L, Cortese F, Artemov A, Karpinsky-Semper D, Moskalev A, et al. Towards natural mimetics of metformin and rapamycin. Aging (Albany NY) [Internet]. 2017;9(11):2245-68. Available from: 
https://www.ncbi.nlm.nih.gov/pubmed/29165314

24. Harrison DE, Strong R, Sharp ZD, Nelson JF, Astle CM, Flurkey K, et al. Rapamycin fed late in life extends lifespan in genetically heterogeneous mice. Nature [Internet]. 2009;460(7253):392-5. Available from: https://www.ncbi.nlm.nih.gov/pubmed/19587680

25. Nadon NL, Strong R, Miller RA, Harrison DE. NIA Interventions Testing Program: Investigating Putative Aging Intervention Agents in a Genetically Heterogeneous Mouse Model. EBioMedicine [Internet]. 2017;21:34. Available from: https://www.ncbi.nlm.nih.gov/pubmed/27923560

26. Wang T, Tsui B, Kreisberg JF, Robertson NA, Gross AM, Yu MK, et al. Epigenetic aging signatures in mice livers are slowed by dwarfism, calorie restriction and rapamycin treatment. Genome Biol. 2017 Mar $28 ; 18(1): 1-11$.

27. Mannick JB, Del Giudice G, Lattanzi M, Valiante NM, Praestgaard J, Huang B, et al. mTOR inhibition improves immune function in the elderly. Sci Transl Med. 2014/12/30. 2014;6(268):268ra179.

28. Mortality GBD, Causes of Death C. Global, regional, and national life expectancy, all-cause mortality, and cause-specific mortality for 249 causes of death, 1980-2015: a systematic analysis for the Global Burden of Disease Study 2015. Lancet [Internet]. 2016;388(10053):1459-544. Available from: https://www.ncbi.nlm.nih.gov/pubmed/27733281

29. North BJ, Sinclair DA. The intersection between aging and cardiovascular disease. Circ Res [Internet]. 2012;110(8):1097-108. Available from: https://www.ncbi.nlm.nih.gov/pubmed/22499900

30. Yazdanyar A, Newman AB. The burden of cardiovascular disease in the elderly: morbidity, mortality, and costs. Clin Geriatr Med [Internet]. 2009;25(4):563-77, vii. Available from: https://www.ncbi.nlm.nih.gov/pubmed/19944261

31. Xu T, Brandmaier S, Messias AC, Herder C, Draisma HH, Demirkan A, et al. Effects of metformin on metabolite profiles and LDL cholesterol in patients with type 2 diabetes. Diabetes Care. 2015/08/08. 2015;38(10):1858-67.

32. Adeyemo MA, Mcduffie JR, Kozlosky M, Krakoff J, Calis KA, Brady SM, et al. Effects of metformin on energy intake and satiety in obese children. Diabetes, Obes Metab. 2015;

33. Day EA, Ford RJ, Smith BK, Mohammadi-Shemirani P, Morrow MR, Gutgesell RM, et al. Metformininduced increases in GDF15 are important for suppressing appetite and promoting weight loss. Nat Metab [Internet]. 2019;1(12):1202-8. Available from: https://doi.org/10.1038/s42255-019-0146-4

34. Coll AP, Chen M, Taskar P, Rimmington D, Patel S, Tadross J, et al. GDF15 mediates the effects of metformin on body weight and energy balance. Nature [Internet]. 2019/12/26. 2019; Available from: https://www.ncbi.nlm.nih.gov/pubmed/31875646

35. Au Yeung SL, Luo S, Schooling CM. The impact of GDF-15, a biomarker for metformin, on the risk of coronary artery disease, breast and colorectal cancer, and type 2 diabetes and metabolic traits: a Mendelian randomisation study. Diabetologia [Internet]. 2019 Sep 1 [cited 2020 Jun 30];62(9):1638-46. Available from: https://link.springer.com/article/10.1007/s00125-019-4913-2

36. Isoda K, Young JL, Zirlik A, MacFarlane LA, Tsuboi N, Gerdes N, et al. Metformin inhibits proinflammatory responses and nuclear factor- $\chi \mathrm{B}$ in human vascular wall cells. Arterioscler Thromb Vasc Biol. 2006 ;

37. Karnewar S, Neeli PK, Panuganti D, Kotagiri S, Mallappa S, Jain N, et al. Metformin regulates mitochondrial biogenesis and senescence through AMPK mediated H3K79 methylation: Relevance in ageassociated vascular dysfunction. Biochim Biophys Acta - Mol Basis Dis. 2018 Apr 1;1864(4):1115-28.

38. Zhang YP, Huang YT, Huang TS, Pang W, Zhu JJ, Liu YF, et al. The Mammalian Target of Rapamycin and DNA methyltransferase 1 axis mediates vascular endothelial dysfunction in response to disturbed flow. 
Sci Rep. 2017 Dec 1;7(1):1-12.

39. Zou MH, Kirkpatrick SS, Davis BJ, Nelson JS, Wiles IV WG, Schlattner U, et al. Activation of the AMP-activated protein kinase by the anti-diabetic drug metformin in vivo: Role of mitochondrial reactive nitrogen species. J Biol Chem. 2004;

40. Davis BJ, Xie Z, Viollet B, Zou MH. Activation of the AMP-activated kinase by antidiabetes drug metformin stimulates nitric oxide synthesis in vivo by promoting the association of heat shock protein 90 and endothelial nitric oxide synthase. Diabetes [Internet]. 2006/01/31. 2006;55(2):496-505. Available from: https://www.ncbi.nlm.nih.gov/pubmed/16443786

41. Kanamori H, Naruse G, Yoshida A, Minatoguchi S, Watanabe T, Kawaguchi T, et al. Metformin Enhances Autophagy and Provides Cardioprotection in $\delta$-Sarcoglycan Deficiency-Induced Dilated Cardiomyopathy. Circ Heart Fail [Internet]. 2019 Apr 1 [cited 2020 Jun 23];12(4):e005418. Available from: http://www.ncbi.nlm.nih.gov/pubmed/30922066

42. Roumie CL, Hung AM, Greevy RA, Grijalva CG, Liu X, Murff HJ, et al. Comparative effectiveness of sulfonylurea and metformin monotherapy on cardiovascular events in type 2 diabetes mellitus: a cohort study. Ann Intern Med [Internet]. 2012/11/07. 2012;157(9):601-10. Available from: https://www.ncbi.nlm.nih.gov/pubmed/23128859

43. Hong J, Zhang Y, Lai S, Lv A, Su Q, Dong Y, et al. Effects of metformin versus glipizide on cardiovascular outcomes in patients with type 2 diabetes and coronary artery disease. Diabetes Care. 2012/12/12. 2013;36(5):1304-11.

44. Holman RR, Paul SK, Bethel MA, Matthews DR, Neil HA. 10-year follow-up of intensive glucose control in type 2 diabetes. $\mathrm{N}$ Engl J Med [Internet]. 2008;359(15):1577-89. Available from: https://www.ncbi.nlm.nih.gov/pubmed/18784090

45. Lexis CP, van der Horst-Schrivers AN, Lipsic E, Valente MA, Muller Kobold AC, de Boer RA, et al. The effect of metformin on cardiovascular risk profile in patients without diabetes presenting with acute myocardial infarction: data from the Glycometabolic Intervention as adjunct to Primary Coronary Intervention in ST Elevation Myocardial Infarction (G. BMJ Open Diabetes Res Care. 2015/12/22. 2015;3(1):e000090.

46. Goldberg RB, Aroda VR, Bluemke DA, Barrett-Connor E, Budoff M, Crandall JP, et al. Effect of LongTerm Metformin and Lifestyle in the Diabetes Prevention Program and Its Outcome Study on Coronary Artery Calcium. Circulation. 2017/05/10. 2017;136(1):52-64.

47. Berger NA, Savvides P, Koroukian SM, Kahana EF, Deimling GT, Rose JH, et al. Cancer in the elderly. Trans Am Clin Clim Assoc [Internet]. 2006;117:146-7. Available from: https://www.ncbi.nlm.nih.gov/pubmed/18528470

48. Guertin DA, Sabatini DM. Defining the role of mTOR in cancer. Cancer Cell [Internet]. 2007;12(1):9-22. Available from: https://www.ncbi.nlm.nih.gov/pubmed/17613433

49. Nitta N, Nakasu S, Shima A, Nozaki K. mTORC1 signaling in primary central nervous system lymphoma. Surg Neurol Int [Internet]. 2016;7(Suppl 17):S475-80. Available from: https://www.ncbi.nlm.nih.gov/pubmed/27512609

50. Liu H, Zhang L, Zhang X, Cui Z. PI3K/AKT/mTOR pathway promotes progestin resistance in endometrial cancer cells by inhibition of autophagy. Onco Targets Ther [Internet]. 2017;10:2865-71. Available from: https://www.ncbi.nlm.nih.gov/pubmed/28652768

51. Majmundar AJ, Wong WJ, Simon MC. Hypoxia inducible factors and the response to hypoxic stress. Mol Cell [Internet]. 2010 [cited 2020 Jun 29];40(2):294. Available from: /pmc/articles/PMC3143508/?report=abstract 
52. Porstmann T, Santos CR, Griffiths B, Cully M, Wu M, Leevers S, et al. SREBP Activity Is Regulated by mTORC1 and Contributes to Akt-Dependent Cell Growth. Cell Metab. 2008;

53. Peterson TR, Sengupta SS, Harris TE, Carmack AE, Kang SA, Balderas E, et al. MTOR complex 1 regulates lipin 1 localization to control the srebp pathway. Cell. 2011;

54. Ben-Sahra I, Howell JJ, Asara JM, Manning BD. Stimulation of de novo pyrimidine synthesis by growth signaling through mTOR and S6K1. Science (80- ). 2013;

55. Guba M, von Breitenbuch P, Steinbauer M, Koehl G, Flegel S, Hornung M, et al. Rapamycin inhibits primary and metastatic tumor growth by antiangiogenesis: involvement of vascular endothelial growth factor. Nat Med [Internet]. 2002;8(2):128-35. Available from: https://www.ncbi.nlm.nih.gov/pubmed/11821896

56. Anisimov VN, Zabezhinski MA, Popovich IG, Piskunova TS, Semenchenko A V, Tyndyk ML, et al. Rapamycin increases lifespan and inhibits spontaneous tumorigenesis in inbred female mice. Cell Cycle. 2011/11/24. 2011;10(24):4230-6.

57. Granville CA, Warfel N, Tsurutani J, Hollander MC, Robertson M, Fox SD, et al. Identification of a highly effective rapamycin schedule that markedly reduces the size, multiplicity, and phenotypic progression of tobacco carcinogen-induced murine lung tumors. Clin Cancer Res. 2007/04/04. 2007;13(7):2281-9.

58. Llovet JM, Hernandez-Gea V. Hepatocellular carcinoma: reasons for phase III failure and novel perspectives on trial design. Clin Cancer Res [Internet]. 2014;20(8):2072-9. Available from: https://www.ncbi.nlm.nih.gov/pubmed/24589894

59. Meng LH, Zheng XF. Toward rapamycin analog (rapalog)-based precision cancer therapy. Acta Pharmacol Sin [Internet]. 2015;36(10):1163-9. Available from: https://www.ncbi.nlm.nih.gov/pubmed/26299952

60. Zhao H, Orhan YC, Zha X, Esencan E, Chatterton RT, Bulun SE. AMP-activated protein kinase and energy balance in breast cancer. Am J Transl Res [Internet]. 2017/03/25. 2017;9(2):197-213. Available from: https://www.ncbi.nlm.nih.gov/pubmed/28337254

61. Anisimov VN, Berstein LM, Popovich IG, Zabezhinski MA, Egormin PA, Piskunova TS, et al. If started early in life, metformin treatment increases life span and postpones tumors in female SHR mice. Aging (Albany NY) [Internet]. 2011/03/10. 2011;3(2):148-57. Available from: https://www.ncbi.nlm.nih.gov/pubmed/21386129

62. Memmott RM, Mercado JR, Maier CR, Kawabata S, Fox SD, Dennis PA. Metformin prevents tobacco carcinogen-induced lung tumorigenesis. Cancer Prev Res. 2010;

63. Mitsuhashi A, Kiyokawa T, Sato Y, Shozu M. Effects of metformin on endometrial cancer cell growth in vivo: a preoperative prospective trial. Cancer. 2014/06/12. 2014;120(19):2986-95.

64. Evans JM, Donnelly LA, Emslie-Smith AM, Alessi DR, Morris AD. Metformin and reduced risk of cancer in diabetic patients. BMJ. 2005/04/26. 2005;330(7503):1304-5.

65. Libby G, Donnelly LA, Donnan PT, Alessi DR, Morris AD, Evans JM. New users of metformin are at low risk of incident cancer: a cohort study among people with type 2 diabetes. Diabetes Care. 2009/07/01. 2009;32(9):1620-5.

66. Chen HP, Shieh JJ, Chang CC, Chen TT, Lin JT, Wu MS, et al. Metformin decreases hepatocellular carcinoma risk in a dose-dependent manner: population-based and in vitro studies. Gut. 2012/07/10. 2013;62(4):606-15.

67. Suissa S, Azoulay L. Metformin and the risk of cancer: time-related biases in observational studies. Diabetes Care [Internet]. 2012/11/23. 2012;35(12):2665-73. Available from: https://www.ncbi.nlm.nih.gov/pubmed/23173135 
68. Zi F, Zi H, Li Y, He J, Shi Q, Cai Z. Metformin and cancer: An existing drug for cancer prevention and therapy. Oncol Lett [Internet]. 2018;15(1):683-90. Available from: https://www.ncbi.nlm.nih.gov/pubmed/29422962

69. Home PD, Kahn SE, Jones NP, Noronha D, Beck-Nielsen H, Viberti G. Experience of malignancies with oral glucose-lowering drugs in the randomised controlled ADOPT (A Diabetes Outcome Progression Trial) and RECORD (Rosiglitazone Evaluated for Cardiovascular Outcomes and Regulation of Glycaemia in Diabetes) clinical trials. Diabetologia. 2010/06/10. 2010;53(9):1838-45.

70. Stevens RJ, Ali R, Bankhead CR, Bethel MA, Cairns BJ, Camisasca RP, et al. Cancer outcomes and all-cause mortality in adults allocated to metformin: systematic review and collaborative meta-analysis of randomised clinical trials. Diabetologia. 2012/08/10. 2012;55(10):2593-603.

71. Thakkar B, Aronis KN, Vamvini MT, Shields K, Mantzoros CS. Metformin and sulfonylureas in relation to cancer risk in type II diabetes patients: a meta-analysis using primary data of published studies. Metabolism. 2013/02/20. 2013;62(7):922-34.

72. Whitehouse PJ, Price DL, Struble RG, Clark AW, Coyle JT, Delon MR. Alzheimer's disease and senile dementia: loss of neurons in the basal forebrain. Science (80- ) [Internet]. 1982;215(4537):1237-9. Available from: https://www.ncbi.nlm.nih.gov/pubmed/7058341

73. Alzheimer's A. 2015 Alzheimer's disease facts and figures. Alzheimers Dement [Internet]. 2015;11(3):33284. Available from: https://www.ncbi.nlm.nih.gov/pubmed/25984581

74. Woodruff-Pak DS, Vogel RW, Wenk GL. Galantamine: Effect on nicotinic receptor binding, acetylcholinesterase inhibition, and learning. Proc Natl Acad Sci [Internet]. 2001 Feb 13 [cited 2019 Nov 10];98(4):2089-94. Available from: http://www.ncbi.nlm.nih.gov/pubmed/11172080

75. Birks JS, Chong LY, Grimley Evans J. Rivastigmine for Alzheimer's disease [Internet]. Vol. 2015, Cochrane Database of Systematic Reviews. John Wiley and Sons Ltd; 2015 [cited 2020 Jun 29]. Available from: https://www.cochranelibrary.com/cdsr/doi/10.1002/14651858.CD001191.pub4/full

76. Korabecny J, Spilovska K, Mezeiova E, Benek O, Juza R, Kaping D, et al. A Systematic Review on Donepezil-based Derivatives as Potential Cholinesterase Inhibitors for Alzheimer's Disease. Curr Med Chem [Internet]. 2019 Oct 26 [cited 2019 Nov 10];26(30):5625-48. Available from: http://www.ncbi.nlm.nih.gov/pubmed/29768996

77. Kishi T, Matsunaga S, Oya K, Nomura I, Ikuta T, Iwata N. Memantine for Alzheimer's Disease: An Updated Systematic Review and Meta-analysis. J Alzheimer's Dis [Internet]. 2017 Sep 18 [cited 2019 Nov 10];60(2):401-25. Available from: http://www.ncbi.nlm.nih.gov/pubmed/28922160

78. Koenig AM, Mechanic-Hamilton D, Xie SX, Combs MF, Cappola AR, Xie L, et al. Effects of the Insulin Sensitizer Metformin in Alzheimer Disease. Alzheimer Dis Assoc Disord [Internet]. 2017 [cited 2019 Nov 10];31(2):107-13. Available from: http://www.ncbi.nlm.nih.gov/pubmed/28538088

79. Imfeld P, Bodmer M, Jick SS, Meier CR. Metformin, Other Antidiabetic Drugs, and Risk of Alzheimer's Disease: A Population-Based Case-Control Study. J Am Geriatr Soc [Internet]. 2012 May 1 [cited 2019 Nov 10];60(5):916-21. Available from: http://doi.wiley.com/10.1111/j.1532-5415.2012.03916.x

80. Chen Y, Zhou K, Wang R, Liu Y, Kwak Y-D, Ma T, et al. Antidiabetic drug metformin (GlucophageR) increases biogenesis of Alzheimer's amyloid peptides via up-regulating BACE1 transcription. Proc Natl Acad Sci U S A [Internet]. 2009 Mar 10 [cited 2019 Nov 10];106(10):3907-12. Available from: http://www.ncbi.nlm.nih.gov/pubmed/19237574

81. Li J, Deng J, Sheng W, Zuo Z. Metformin attenuates Alzheimer's disease-like neuropathology in obese, leptin-resistant mice. Pharmacol Biochem Behav [Internet]. 2012 Jun 1 [cited 2019 Nov 10];101(4):564-74. Available from: https://www.sciencedirect.com/science/article/pii/S0091305712000640?via\%3Dihub 
82. Tramutola A, Triplett JC, Di Domenico F, Niedowicz DM, Murphy MP, Coccia R, et al. Alteration of mTOR signaling occurs early in the progression of Alzheimer disease (AD): Analysis of brain from subjects with pre-clinical AD, amnestic mild cognitive impairment and late-stage AD. J Neurochem. 2015;

83. Lu AT, Hannon E, Levine ME, Hao K, Crimmins EM, Lunnon K, et al. Genetic variants near MLST8 and DHX57 affect the epigenetic age of the cerebellum. Nat Commun [Internet]. 2016 Feb 2 [cited 2020 Jun 28];7(1):1-9. Available from: https://www.nature.com/articles/ncomms10561

84. Caccamo A, Magrì A, Medina DX, Wisely E V, López-Aranda MF, Silva AJ, et al. mTOR regulates tau phosphorylation and degradation: Implications for Alzheimer's disease and other tauopathies. Aging Cell. 2013 ;

85. Caccamo A, Majumder S, Richardson A, Strong R, Oddo S. Molecular interplay between mammalian target of rapamycin (mTOR), amyloid-beta, and Tau: effects on cognitive impairments. J Biol Chem. 2010/02/25. 2010;285(17):13107-20.

86. Majumder S, Richardson A, Strong R, Oddo S. Inducing autophagy by rapamycin before, but not after, the formation of plaques and tangles ameliorates cognitive deficits. PLoS One. 2011;

87. Lin AL, Jahrling JB, Zhang W, DeRosa N, Bakshi V, Romero P, et al. Rapamycin rescues vascular, metabolic and learning deficits in apolipoprotein E4 transgenic mice with pre-symptomatic Alzheimer's disease. J Cereb Blood Flow Metab. 2016/01/02. 2017;37(1):217-26.

88. Palacios N, Gao X, McCullough ML, Jacobs EJ, Patel A V, Mayo T, et al. Obesity, diabetes, and risk of Parkinson's disease. Mov Disord [Internet]. 2011;26(12):2253-9. Available from: https://www.ncbi.nlm.nih.gov/pubmed/21739472

89. Tysnes OB, Storstein A. Epidemiology of Parkinson's disease. J Neural Transm [Internet]. 2017;124(8):901-5. Available from: https://www.ncbi.nlm.nih.gov/pubmed/28150045

90. Djamshidian A, Poewe W. Apomorphine and levodopa in Parkinson's disease: Two revolutionary drugs from the 1950's. Parkinsonism Relat Disord [Internet]. 2016 Dec [cited 2019 Nov 10];33:S9-12. Available from: http://www.ncbi.nlm.nih.gov/pubmed/28012951

91. Weinreb O, Amit T, Bar-Am O, Youdim MBH. Rasagiline: A novel anti-Parkinsonian monoamine oxidaseB inhibitor with neuroprotective activity. Prog Neurobiol [Internet]. 2010 Nov [cited 2019 Nov 10];92(3):33044. Available from: http://www.ncbi.nlm.nih.gov/pubmed/20600573

92. Mindham RHS, Lamb P, Bradley R. A Comparison of Piribedil, Procyclidine and Placebo in the Control of Phenothiazine-induced Parkinsonism. Br J Psychiatry [Internet]. 1977 Jun 29 [cited 2019 Nov 10];130(6):5815. Available from: http://www.ncbi.nlm.nih.gov/pubmed/326325

93. Wahlqvist ML, Lee M-S, Hsu C-C, Chuang S-Y, Lee J-T, Tsai H-N. Metformin-inclusive sulfonylurea therapy reduces the risk of Parkinson's disease occurring with Type 2 diabetes in a Taiwanese population cohort. Parkinsonism Relat Disord [Internet]. 2012 Jul [cited 2019 Nov 10];18(6):753-8. Available from: http://www.ncbi.nlm.nih.gov/pubmed/22498320

94. Przedborski S, Vila M. MPTP: A review of its mechanisms of neurotoxicity. Vol. 1, Clinical Neuroscience Research. 2001. p. 407-18.

95. Katila N, Bhurtel S, Shadfar S, Srivastav S, Neupane S, Ojha U, et al. Metformin lowers $\alpha$-synuclein phosphorylation and upregulates neurotrophic factor in the MPTP mouse model of Parkinson's disease. Neuropharmacology [Internet]. 2017 Oct 1 [cited 2019 Nov 10];125:396-407. Available from: https://www.sciencedirect.com/science/article/pii/S0028390817303829

96. Fitzgerald JC, Zimprich A, Carvajal Berrio DA, Schindler KM, Maurer B, Schulte C, et al. Metformin reverses TRAP1 mutation-associated alterations in mitochondrial function in Parkin- 
son's disease. Brain [Internet]. 2017 Sep 1 [cited 2019 Nov 10];140(9):2444-59. Available from: https://academic.oup.com/brain/article/140/9/2444/4096700

97. Slack C, Foley A, Partridge L. Activation of AMPK by the putative dietary restriction mimetic metformin is insufficient to extend lifespan in Drosophila. PLoS One [Internet]. 2012;7(10):e47699. Available from: https://www.ncbi.nlm.nih.gov/pubmed/23077661

98. McCreight LJ, Bailey CJ, Pearson ER. Metformin and the gastrointestinal tract. Diabetologia [Internet]. 2016/01/19. 2016;59(3):426-35. Available from: https://www.ncbi.nlm.nih.gov/pubmed/26780750

99. Liu Q, Li S, Quan H, Li J. Vitamin B12 status in metformin treated patients: systematic review. PLoS One [Internet]. 2014;9(6):e100379. Available from: https://www.ncbi.nlm.nih.gov/pubmed/24959880

100. Aroda VR, Edelstein SL, Goldberg RB, Knowler WC, Marcovina SM, Orchard TJ, et al. Long-term Metformin Use and Vitamin B12 Deficiency in the Diabetes Prevention Program Outcomes Study. J Clin Endocrinol Metab [Internet]. 2016;101(4):1754-61. Available from: https://www.ncbi.nlm.nih.gov/pubmed/26900641

101. Administration USF and D. Rapamune Prescribing Information [Internet]. 2015. Available from: https://www.accessdata.fda.gov/drugsatfda_docs/label/2015/021083s058,021110s075lbl.pdf

102. Kraig E, Linehan LA, Liang H, Romo TQ, Liu Q, Wu Y, et al. A randomized control trial to establish the feasibility and safety of rapamycin treatment in an older human cohort: Immunological, physical performance, and cognitive effects. Exp Gerontol [Internet]. 2018;105:53-69. Available from: https://www.ncbi.nlm.nih.gov/pubmed/29408453

103. Arriola Apelo SI, Pumper CP, Baar EL, Cummings NE, Lamming DW. Intermittent Administration of Rapamycin Extends the Life Span of Female C57BL/6J Mice. J Gerontol A Biol Sci Med Sci [Internet]. 2016;71(7):876-81. Available from: https://www.ncbi.nlm.nih.gov/pubmed/27091134

104. Azoulay L, Schneider-Lindner V, Dell'aniello S, Schiffrin A, Suissa S. Combination therapy with sulfonylureas and metformin and the prevention of death in type 2 diabetes: a nested case-control study. Pharmacoepidemiol Drug Saf. 2010/01/07. 2010;19(4):335-42.

105. Schreiber KH, Arriola Apelo SI, Yu D, Brinkman JA, Velarde MC, Syed FA, et al. A novel rapamycin analog is highly selective for mTORC1 in vivo. Nat Commun [Internet]. 2019/07/22. 2019;10(1):3194. Available from: https://www.ncbi.nlm.nih.gov/pubmed/31324799

106. Mannick JB, Morris M, Hockey HP, Roma G, Beibel M, Kulmatycki K, et al. TORC1 inhibition enhances immune function and reduces infections in the elderly. Sci Transl Med. 2018/07/13. 2018;10(449).

107. Matter MS, Decaens T, Andersen JB, Thorgeirsson SS. Targeting the mTOR pathway in hepatocellular carcinoma: current state and future trends. J Hepatol [Internet]. 2014;60(4):855-65. Available from: https://www.ncbi.nlm.nih.gov/pubmed/24308993

108. Chiarini F, Evangelisti C, McCubrey JA, Martelli AM. Current treatment strategies for inhibiting mTOR in cancer. Trends Pharmacol Sci [Internet]. 2015;36(2):124-35. Available from: https://www.ncbi.nlm.nih.gov/pubmed/25497227

109. Dykens JA, Will Y. Mitochondrial Toxicity. In: Encyclopedia of Toxicology: Third Edition. Elsevier; 2014. p. 349-53.

110. Kalyanaraman B, Cheng G, Hardy M, Ouari O, Sikora A, Zielonka J, et al. Mitochondria-targeted metformins: Antitumour and redox signalling mechanisms [Internet]. Vol. 7, Interface Focus. Royal Society; 2017 [cited 2020 Jul 1]. Available from: /pmc/articles/PMC5311906/?report=abstract

111. Anisimov VN, Piskunova TS, Popovich IG, Zabezhinski MA, Tyndyk ML, Egormin PA, et al. Gender differences in metformin effect on aging, life span and spontaneous tumorigenesis in 129/Sv mice. Aging (Albany NY) [Internet]. 2010;2(12):945-58. Available from: https://www.ncbi.nlm.nih.gov/pubmed/21164223 
112. Miller RA, Harrison DE, Astle CM, Fernandez E, Flurkey K, Han M, et al. Rapamycin-mediated lifespan increase in mice is dose and sex dependent and metabolically distinct from dietary restriction. Aging Cell [Internet]. 2014;13(3):468-77. Available from: https://www.ncbi.nlm.nih.gov/pubmed/24341993

113. Trilla-Fuertes L, Gámez-Pozo A, Arevalillo JM, Díaz-Almirón M, Prado-Vázquez G, Zapater-Moros A, et al. Molecular characterization of breast cancer cell response to metabolic drugs. Oncotarget [Internet]. 2018 [cited 2020 Jun 30];9(11):9645-60. Available from: /pmc/articles/PMC5839391/?report=abstract

114. Zhou Y, Guo Y, Ye W, Wang Y, Li X, Tian Y, et al. RS11212617 is associated with metformin treatment response in type 2 diabetes in Shanghai local Chinese population. Int J Clin Pr [Internet]. 2014;68(12):1462-6. Available from: https://www.ncbi.nlm.nih.gov/pubmed/25296556

115. López-Bermejo A, Díaz M, Morán E, De Zegher F, Ibáñez L. A single nucleotide polymorphism in STK11 influences insulin sensitivity and metformin efficacy in hyperinsulinemic girls with androgen excess. Diabetes Care [Internet]. 2010 Jul [cited 2020 Jun 30];33(7):1544-8. Available from: /pmc/articles/PMC2890356/?report=abstract

116. Jablonski KA, McAteer JB, De Bakker PIW, Franks PW, Pollin TI, Hanson RL, et al. Common variants in 40 genes assessed for diabetes incidence and response to metformin and lifestyle intervention in the diabetes prevention program. Diabetes [Internet]. 2010 Oct [cited 2020 Jun 30];59(10):2672-81. Available from: https://pubmed.ncbi.nlm.nih.gov/20682687/

117. Zhou K, Bellenguez C, Spencer CCA, Bennett AJ, Coleman RL, Tavendale R, et al. Common variants near ATM are associated with glycemic response to metformin in type 2 diabetes [Internet]. Vol. 43, Nature Genetics. Nat Genet; 2011 [cited 2020 Jun 30]. p. 117-20. Available from: https://pubmed.ncbi.nlm.nih.gov/21186350/

118. Barzilai N, Crandall JP, Kritchevsky SB, Espeland MA. Metformin as a Tool to Target Aging. Cell Metab. 2016/06/16. 2016;23(6):1060-5.

119. World's first anti-aging TAME trial gets green-light - Longevity.Technology [Internet]. [cited 2020 Jul 1]. Available from: https://www.longevity.technology/worlds-first-anti-aging-trial-gets-green-light/

Table 1. Summary of major animal studies and clinical trials about the effects of metformin and rapamycin

\begin{tabular}{|c|c|c|c|}
\hline Study & Organisms & Application scheme & Effect \\
\hline Metformin & Metformin & Metformin & Metformin \\
\hline Life extension effect & Life extension effect & Life extension effect & Life extension effect \\
\hline Slack $2012^{97}$ & Fruit flies & $1,10,100 \mathrm{mM}$, every day & $\begin{array}{l}1-10 \mathrm{mM} \text {, no effect on } \\
\text { survival; }>10 \mathrm{mM} \text {, } \\
\text { lifespan decrease Increase } \\
\text { mean lifespan by } 18 \% \text {, } \\
36 \%, 3 \%\end{array}$ \\
\hline Cabreiro $2013^{20}$ & C. elegans & $\begin{array}{l}25,50,100 \mathrm{mM} \text {, every } \\
\text { day }\end{array}$ & $\begin{array}{l}\text { Increase mean lifespan } \\
\text { by } 14 \%, 6 \%, 0 \%\end{array}$ \\
\hline Martin-Montalvo $2013^{21}$ & Mice & $\begin{array}{l}100 \mathrm{mg} / \mathrm{kg} \text {, every day, } \\
\text { started at } 3,9 \text { or } 15 \\
\text { months }\end{array}$ & $\begin{array}{l}0.1 \% \text {, lifespan increase by } \\
5.83 \% ; 1 \% \text {, lifespan } \\
\text { decrease by } 14.4 \%\end{array}$ \\
\hline
\end{tabular}




\begin{tabular}{|c|c|c|c|}
\hline Study & Organisms & Application scheme & Effect \\
\hline Zhong $2017^{19}$ & Human & $\begin{array}{l}\text { Initial dose: } 750 \mathrm{mg} / \text { day; } \\
\text { increased weekly up to } \\
1500 \text { or } 2250 \mathrm{mg} / \text { day for } \\
3 \text { - } 12 \text { weeks }\end{array}$ & $\begin{array}{l}\text { Increase in AMPK } \\
\text { phosphorylation; } \\
\text { Decreased tumor cell } \\
\text { proliferation; Decreased } \\
\text { H19 levels; Increased } \\
\text { methylation in genes } \\
\text { H19, DMRTA2, KCNG2 } \\
\text { PSMD10, TRA2A }\end{array}$ \\
\hline Anticancer effect & Anticancer effect & Anticancer effect & Anticancer effect \\
\hline Mitsuhashi $2014^{63}$ & Human & $\begin{array}{l}1500-2250 \mathrm{mg} / \text { day, for } \\
4 \text { to } 6 \text { weeks }\end{array}$ & $\begin{array}{l}\text { Inhibited endometrial } \\
\text { cancer cells grow in } \\
\text { vivo }\end{array}$ \\
\hline Anisimov $2011^{61}$ & Mice & $\begin{array}{l}100 \mathrm{mg} / \mathrm{kg} \text {-bodyweight } \\
\text { starting at the age of } 3 \\
\text { months, } 9 \text { months, and } \\
15 \text { months }\end{array}$ & $\begin{array}{l}\text { Delayed tumor onset } \\
\text { by } 22 \% \text { and } 25 \% \\
\text { respectively at the age } \\
\text { of } 3 \text { months and } 9 \\
\text { months }\end{array}$ \\
\hline H. P. Chen $2013^{66}$ & Human & $\begin{array}{l}\text { Based on the condition } \\
\text { of patients with type } 2 \\
\text { diabetes mellitus }\end{array}$ & $\begin{array}{l}\text { Hepatocellular } \\
\text { carcinoma risk } \\
\text { decreases }\end{array}$ \\
\hline $\begin{array}{l}\text { Reduce cardiovascu- } \\
\text { lar disease } \\
\text { risk }\end{array}$ & $\begin{array}{l}\text { Reduce cardiovascu- } \\
\text { lar disease } \\
\text { risk }\end{array}$ & $\begin{array}{l}\text { Reduce cardiovascu- } \\
\text { lar disease } \\
\text { risk }\end{array}$ & $\begin{array}{l}\text { Reduce cardiovascu- } \\
\text { lar disease } \\
\text { risk }\end{array}$ \\
\hline Lexis $2015^{45}$ & Human & $\begin{array}{l}\text { ST-segment elevation } \\
\text { myocardial infarction } \\
\text { (STEMI) patients, } 500 \\
\text { mg twice daily, for } 4 \\
\text { months }\end{array}$ & $\begin{array}{l}\text { Cardiovascular risk } \\
\text { decreases }\end{array}$ \\
\hline Goldberg $2017^{46}$ & Human & $\begin{array}{l}850 \mathrm{mg} \text { twice daily, for } \\
\text { over } 3.2 \text { years }\end{array}$ & $\begin{array}{l}\text { Coronary } \\
\text { atherosclerosis risk } \\
\text { decreases }\end{array}$ \\
\hline Karnewar $2018^{37}$ & Mice & $\begin{array}{l}50 \mathrm{mg} / \mathrm{kg} \text {-bodyweight for } \\
14 \mathrm{months}\end{array}$ & $\begin{array}{l}\text { Ameliorated age-related } \\
\text { atherosclerosis; } \\
\text { Significantly reduced } \\
\text { macrophage recruitment } \\
\text { and inflammatory } \\
\text { cytokines }\end{array}$ \\
\hline Kanamori $2019^{41}$ & Mice & $\begin{array}{l}200 \mathrm{mg} / \mathrm{kg} \text {-bodyweight } \\
\text { per day for } 4 \text { weeks }\end{array}$ & $\begin{array}{l}\text { Partially reversed left } \\
\text { ventricular dilatation } \\
\text { caused by } \\
\delta \text {-sarcoglycan } \\
\text { deficiency }\end{array}$ \\
\hline $\begin{array}{l}\text { Anti-Alzheimer's } \\
\text { disease effect }\end{array}$ & $\begin{array}{l}\text { Anti-Alzheimer's } \\
\text { disease effect }\end{array}$ & $\begin{array}{l}\text { Anti-Alzheimer's } \\
\text { disease effect }\end{array}$ & $\begin{array}{l}\text { Anti-Alzheimer's } \\
\text { disease effect }\end{array}$ \\
\hline Chen $2009^{80}$ & Mice & $2-5 \mathrm{mg} / \mathrm{mL}$ for 6 days & $\begin{array}{l}\text { Both intracellular and } \\
\text { extracellular } A \beta \text { species } \\
\text { increases }\end{array}$ \\
\hline Li $2012^{81}$ & Mice & $\begin{array}{l}200 \mathrm{mg} \mathrm{kg-}{ }^{1} \mathrm{~d}-^{1} \text { for } 18 \\
\text { weeks }\end{array}$ & $\begin{array}{l}\text { AD-like biochemical } \\
\text { changes decrease }\end{array}$ \\
\hline
\end{tabular}




\begin{tabular}{|c|c|c|c|}
\hline Study & Organisms & Application scheme & Effect \\
\hline Koenig $2017^{78}$ & Human & $\begin{array}{l}\text { Metformin or placebo } \\
\text { for } 8 \text { weeks }\end{array}$ & $\begin{array}{l}\text { Executive functioning } \\
\text { improves }\end{array}$ \\
\hline Anti- & Anti- & Anti- & Anti- \\
\hline $\begin{array}{l}\text { Parkinson's disease } \\
\text { effect }\end{array}$ & $\begin{array}{l}\text { Parkinson's disease } \\
\text { effect }\end{array}$ & $\begin{array}{l}\text { Parkinson's disease } \\
\text { effect }\end{array}$ & $\begin{array}{l}\text { Parkinson's disease } \\
\text { effect }\end{array}$ \\
\hline Katila $2017^{95}$ & Mice & $\begin{array}{l}200 \mathrm{mg} \mathrm{kg-}{ }^{1} \mathrm{~d}^{-1} \text { for } 7 \\
\text { days }\end{array}$ & $\begin{array}{l}\text { Metformin provides } \\
\text { neuroprotection against } \\
\text { MPTP neurotoxicity }\end{array}$ \\
\hline \multicolumn{4}{|l|}{ Rapamycin } \\
\hline Life extension effect & Life extension effect & Life extension effect & Life extension effect \\
\hline Aliper $2017^{23}$ & Yeasts & $\begin{array}{l}100,300,600 \\
1000 \mathrm{pg} / \mathrm{mL} \text { in the } \\
\text { culture medium }\end{array}$ & $\begin{array}{l}\text { Lifespan increase in a } \\
\text { dose-responsive manner }\end{array}$ \\
\hline Harrison $2009^{24}$ & Mice & $\begin{array}{l}\text { Begins at } 600 \text { days, } 14.7 \\
\mathrm{mg} / \mathrm{kg}\end{array}$ & $\begin{array}{l}\text { females' lifespan increases } \\
\text { by } 14 \% \text {; males' lifespan } \\
\text { increases by } 9 \%\end{array}$ \\
\hline Miller $2014^{112}$ & Mice & $\begin{array}{l}\text { Begins at } 3 \text { months, } \\
\text { everyday }\end{array}$ & $\begin{array}{l}\text { females, lifespan } \\
\text { increase by } 26 \% \text {; males, } \\
\text { lifespan increase by } \\
23 \%\end{array}$ \\
\hline Mannick $2014^{27}$ & Human & $\begin{array}{l}0.5 \mathrm{mg} \text { daily, or } 5 \mathrm{mg} \\
\text { weekly, or } 20 \mathrm{mg} \\
\text { weekly for } 6 \text { weeks }\end{array}$ & $\begin{array}{l}20 \% \text { improved response } \\
\text { to influenza vaccine }\end{array}$ \\
\hline Wang $2017^{26}$ & Mice & $\begin{array}{l}42 \mathrm{mg} / \mathrm{kg} \text {-bodyweight } \\
\text { dietary rapamycin } \\
\text { treatment from } 4 \text { to } 22 \\
\text { months }\end{array}$ & $\begin{array}{l}\text { Had 6-month decrease } \\
\text { in epigenetic age } \\
\text { compared to control }\end{array}$ \\
\hline Anticancer effect & Anticancer effect & Anticancer effect & Anticancer effect \\
\hline Guba $2002^{55}$ & Mice & $\begin{array}{l}1.5 \mathrm{mg} / \mathrm{kg} / \mathrm{d} \text {, begins on } \\
\text { day } 0 \text { or } 7 \text { relative to } \\
\text { tumor implantation }\end{array}$ & $\begin{array}{l}\text { Inhibited liver tumors } \\
\text { grow }\end{array}$ \\
\hline Granville $2007^{57}$ & Mice & $\begin{array}{l}1 \text { weeks after NNK } \\
\text { administration }\end{array}$ & $\begin{array}{l}\text { Tumors show decreased } \\
\text { phenotypic progression } \\
\text { and a } 74 \% \text { decrease in } \\
\text { size }\end{array}$ \\
\hline Anisimov $2011^{56}$ & Mice & $\begin{array}{l}\text { Begins at } 2 \text { months , } 3 \\
\text { times a week, for } 2 \\
\text { weeks, followed by a } 2 \\
\text { weeks break, for } 2 \text { years }\end{array}$ & $\begin{array}{l}\text { Shifted the tumor-yield } \\
\text { curve to the right and } \\
\text { prolonged mean } \\
\text { lifespan }\end{array}$ \\
\hline Anti-Alzheimer's & Anti-Alzheimer's & Anti-Alzheimer's & Anti-Alzheimer's \\
\hline Disease effect & Disease effect & Disease effect & Disease effect \\
\hline Caccamo $2010^{85}$ & Mice & $2.24 \mathrm{mg} / \mathrm{kg}$, every day & $\begin{array}{l}\text { RAPA improves } \\
\text { learning and memory } \\
\text { and reduces } A \beta \text { and } \\
\text { tau pathology. }\end{array}$ \\
\hline Lin $2017^{87}$ & Mice & $14 \mathrm{mg} / \mathrm{kg}$, every day & $\begin{array}{l}\text { Block progression of } \\
\text { early cognitive deficits }\end{array}$ \\
\hline
\end{tabular}

Table 2. A summary of major studies that have shown the effects of SNPs on metformin/rapamycin therapy 


\begin{tabular}{|c|c|c|c|}
\hline Study & SNP & Gene & Effect \\
\hline Metformin & Metformin & Metformin & Metformin \\
\hline $\begin{array}{l}\text { Trilla-Fuertes L } \\
2018^{113}\end{array}$ & rs2282143 & SLC22A1 & $\begin{array}{l}\text { Affecting the efficiency } \\
\text { of metformin entering } \\
\text { cells }\end{array}$ \\
\hline $\begin{array}{l}\text { Lopez-Bermejo A } \\
2010^{115}\end{array}$ & rs8111699 & LKB1 & $\begin{array}{l}\text { Influencing both } \\
\text { insulin sensitivity and } \\
\text { metformin efficacy in } \\
\text { hyperinsulinemic girls } \\
\text { with androgen excess }\end{array}$ \\
\hline Jablonski KA $2010^{116}$ & rs11212617 & ATM & $\begin{array}{l}\text { Affecting glycemic } \\
\text { response to metformin }\end{array}$ \\
\hline Zhou $2011^{117}$ & rs9803799 & PRKAA2 & $\begin{array}{l}\text { Affecting generation of } \\
\text { AMPK }\end{array}$ \\
\hline Rapamycin & Rapamycin & Rapamycin & Rapamycin \\
\hline $\begin{array}{l}\text { Trilla-Fuertes L } \\
2018^{113}\end{array}$ & rs2740574 & CYP3A4 & $\begin{array}{l}\text { Affecting the } \\
\text { metabolism of } \\
\text { rapamycin in the liver }\end{array}$ \\
\hline $\mathrm{Lu} 2016^{83}$ & rs6723868 & DHX57 & $\begin{array}{l}\text { Correlated with } \\
\text { chronological age }\end{array}$ \\
\hline $\mathrm{Lu} 2016^{83}$ & $\begin{array}{l}\text { rs30986 rs27709 rs26840 } \\
\text { rs27648 }\end{array}$ & $\begin{array}{l}\text { MLST8 MLST8 MLST8 } \\
\text { MLST8 }\end{array}$ & $\begin{array}{l}\text { Correlated with smaller } \\
\text { epigenetic age than } \\
\text { chronological age in the } \\
\text { cerebellum, a part of } \\
\text { mTOR complexes }\end{array}$ \\
\hline
\end{tabular}

Figure Legends

Figure 1. Metformin and Rapamycin could decrease the incidence of age-related diseases.

In terms of mechanism, metformin and rapamycin achieve similar calorie restriction effect in different ways. Metformin can activate AMPK like calorie restriction and further cause a series of pathways changes, which could arouse anti-aging effects such as Inhibition of pro-inflammatory effect and ROS detoxification. Rapamycin can inhibit mTORC1, which relate to Autophagy and Protein Synthesis pathway. 


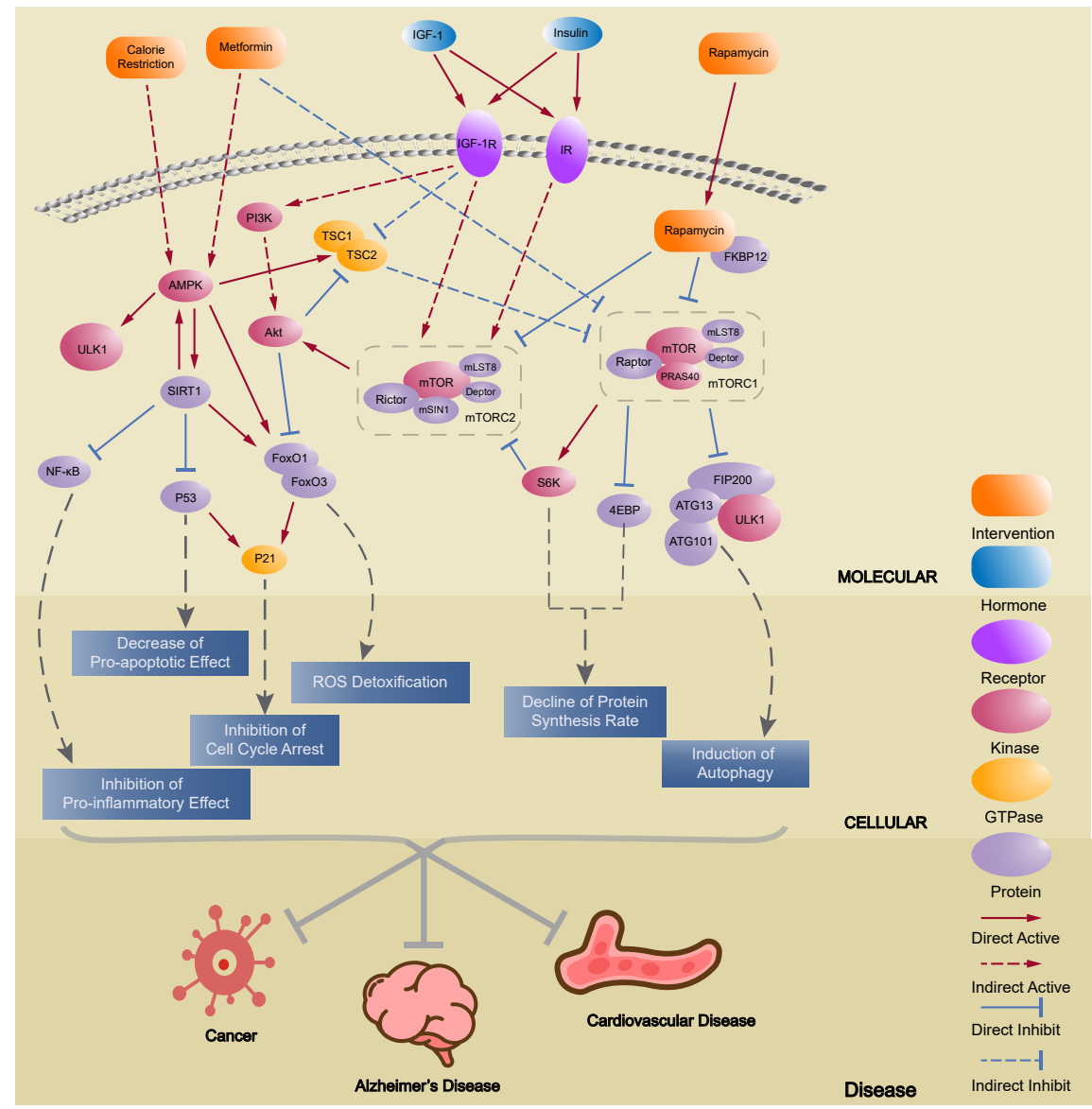

